November - 2020

\title{
Growth and Collaboration in Massive Open Online Courses: A Bibliometric Analysis
}

Ratnaria Wahid, Aidi Ahmi, and A.S.A. Ferdous Alam

Universiti Utara Malaysia

\begin{abstract}
Massive open online courses (MOOCs) are an important approach for achieving UNESCO's aim of open and accessible education. However, there are concerns regarding fragmentation or bias of MOOCs toward certain disciplines or countries. This study sought to: (a) examine how MOOCs research has evolved and is distributed, (b) determine what key areas are discussed in MOOCs research, and (c) identify the major players in MOOCs research and their collaborations. This study conducted a bibliometric analysis of 3,118 scholarly works related to MOOCs as recorded in the Scopus database in July, 2019. Specifically, we analyzed the evolution of MOOCs research by examining (a) published studies, (b) source titles, (c) types of sources and documents, as well as (d) the languages in which the documents were written in. We further analyzed the key areas of MOOCs research by looking into common subject areas, keywords used most often, and title analysis. Finally, we sought to increase our understanding of the major players in MOOCs research and their collaborations by examining (a) which countries contributed most to MOOCs research, (b) the main institutions involved, as well as (c) authorship and citation analysis. Findings indicated that in their early development starting in 2009, MOOCs caught the attention of scholars from both the East and the West, and the number of publications grew consistently over the 10 years after that. MOOCs research has been well distributed but has yet to adequately encourage inclusiveness. There has been healthy cross-country collaboration, but there is a gap in MOOCs research originating from certain countries as compared to the rest of the world. Our findings provide important input towards improving the inclusivity and global reach of MOOCs.
\end{abstract}

Keywords: massive open online courses, MOOCs, distance education, online learning, collaborative research, inclusiveness 


\section{Introduction}

Education is a human right, and massive open online courses (MOOCs) are an important tool whereby digital technology may be used to enhance access to quality education and lifelong learning opportunities for all. The number of MOOC offerings has grown exponentially, partly due to the Internet revolution as well as in response to the call to address the need for access to quality education in an equitable and affordable manner as inspired by the United Nations Sustainable Development Goal 4, which forms part of a universal agenda (United Nations General Assembly, 2015). In the period between 2012 to 2013, MOOCs came to be widely accepted by universities around the world, and outsourcing companies were launched to provide the necessary infrastructure (Baggaley, 2013). Since then, MOOCs have been a popular research topic-rapidly developing, while inspiring new approaches, innovations, assessments, and discussions.

Several studies have looked into trends in MOOCs research. Review studies have not only focused on different time periods, but have also examined different research goals, perspectives, and contributions. Liyanagunawardena, Adams, and Williams (2013) presented the first systematic review of MOOCs literature. They looked at the period from 2008 to 2012, categorized 45 specific pieces of literature into 8 different areas, and analyzed on the basis of types of publications, year of publication, and contributors. Since then, the literature on MOOCs has grown, so it is important to examine the latest developments.

Several studies have looked into the interdisciplinary aspects of MOOCs research. Studies revealed common research themes (Ebben \& Murphy, 2014; Gašević, Kovanović, Joksimović, \& Siemens, 2014), as well as research methods used and dominance of researchers from the field of education (Gašević et al., 2014). Gašević et al. (2014) also raised the concern of fragmentation in the research community and the need to enhance interdisciplinary efforts, but their study focused only on proposals submitted to the MOOC Research Initiative. Similarly, Veletsianos and Shepherdson (2015) found that MOOCs research published from 2013 to 2015 was mostly conducted by researchers from the education and computer science disciplines, though an interdisciplinary trend was also emerging. Veletsianos and Shepherdson (2016) further examined the geographic distribution, publication outlets, citations, data collection, and analysis methods of research focusing on MOOCs during 2013 to 2015. This study, however, excluded literature authored in languages other than English, and recommended that future research examine whether MOOC literature was biased towards certain countries or regions.

Other aspects of MOOCs research have also been studied. Deng and Benckendorff (2017) indicated that most research has used surveys, interviews, and logged files to understand instructors' and students' use of MOOCs. Ichimura and Suzuki (2017) analyzed literature focusing on MOOC course design. Zancanaro and Domingues (2017) analyzed 294 papers on MOOCs. They (a) investigated the number of publications, (b) mapped the institutions involved, (c) looked at authors with the most publications, (d) classified themes, and (e) examined the most frequently cited articles to reveal the emerging and most promising trends of MOOCs. Zhu, Sari, and Lee (2018) explored 146 empirical MOOCs research articles published between 2014 and 2016, and looked into research methods, research focus, as well as geographical distribution of the various research projects. They then extended their research by comparing data from 2014 to 2016 with data from 2016 to 2017. They found that most authors collaborated within the same country and most research on MOOCs originated from the U.S., U.K., Spain, and China (Zhu, Sari, \& Bonk, 2018). However, these studies looked at only a small amount of MOOC literature, which did not show the bigger picture of MOOCs as a global movement. 
Previous studies have focused on understanding MOOCs from various perspectives, but little has been done to determine whether MOOC development is equally shared or collaborated on in different parts of the world. This question is crucial, since MOOCs are viewed as a tool to reduce the educational gap across the world. As MOOCs require technology infrastructure, digital skills, and language fluency, these factors could also potentially increase the digital divide (Jiang, Williams, Warschauer, He, \& O'Dowd, 2014; Lee, Hong, \& Hwang, 2018) and cause serious social polarization across the world. There are also concerns about the often-overlooked cultural dimension of MOOC providers offering global education solutions (Nordin \& Norman, 2018).

This paper presents a bibliometric analysis of scientific literature on MOOCs by looking into three main research questions: (a) how has MOOCs research evolved and been distributed, (b) what key topic areas have been discussed in MOOCs research, and (c) who are the major players in MOOCs research and how have they collaborated. The remainder of this paper offers details on research methods, results and their interpretations, as well as discussion of different considerations and issues involved in answering the research questions above. To answer these three questions, our bibliometric analysis considered the following aspects of the literature on MOOCs.

a) Evolution and distribution of MOOCs research:

- number of published studies per year;

- $\quad$ sources and document types; and

- languages of documents.

b) Key areas of MOOCs research:

- $\quad$ subject area;

- frequency of keywords; and

- $\quad$ title analysis (e.g., frequency of words and phrases).

c) Major players and research collaboration:

- countries with most contributions;

- main institutions;

- $\quad$ authorship analysis; and

- citation analysis.

The purpose of this study was to gain a more in-depth understanding of the MOOC phenomenon, particularly with respect to its global reach and collaborations. It was necessary to examine the latest data in order to help researchers propose recommendations for future research in the development of MOOCs. 


\section{Method}

This bibliometric study accessed the Scopus scientific database to analyze publications with the word MOOC or massive open online learning in their title. It considered all types of documents published in the Scopus database from the year 2009 until 2020. Scopus is one of the largest abstract and citation database of peer-reviewed literature; it contains approximately 23,700 peer-reviewed journals as well as over 24,000 titles, 360 trade publications, 750 book series, 195,000 non-serial books, and 60 million records from various areas of knowledge. Such a large database is able to provide a comprehensive overview of the world's research output. Scopus is also recognized by the international scientific community as one of the main sources of relevant information.

This study employed bibliometric analysis and used quantitative and statistical analysis to describe distribution patterns of research articles within specific topics and time periods (Martí-Parreño, Méndez-Ibáñez, \& Alonso-Arroyo, 2016). The process involved identifying a keyword for search purposes. We used the term mooc* OR "massive open online course" when querying the Scopus database for information on article titles only. The search was conducted on July 17, 2019. The boundaries of the search specified results published from the year 2009 to 2020. Although a bibliometric analysis on MOOCs was conducted by Liyanagunawardena et al. (2013) and covered the initial introduction of MOOCs (i.e., 2008 to 2013), it dealt with different questions and aims. From our search, Scopus returned 3,118 document results, and retrieved several terms related to MOOCs research including MOOC, MOOCs, MOOCAT, MOOCEP, and Mooc-topia.

We analyzed the results in various ways in order to provide input in response to our research questions. Several results were directly retrieved from Scopus through the analyze search results function. Other results were inserted manually or exported to a new Excel file. From the file created for all the results, information such as percentages was analyzed. We also used VOSviewer to generate images to help with data interpretation. After the results were identified, analyzed, and synthesized, we wrote up the final report, which presented the findings and analysis. Through this paper we hope to contribute meaningful insights on the trends apparent in publications on MOOCs. Researchers can use these findings as a basis for future studies and discussions to enrich and further develop this area of research.

\section{Results}

This section deals with the results obtained from the bibliometric analysis related to the following questions: (a) how has MOOCs research evolved and been distributed, (b) what key topic areas have been discussed in MOOCs research, and (c) what are the characteristics of scientific collaborations in MOOCs research among authors in different countries.

\section{Evolution and Dissemination of MOOCs Research}

To address the question of the evolution of MOOCs research and trends in its dissemination, this study analyzed the following data: (a) number of publications by year, (b) source title, (c) source and document type, and (d) document's language.

Publications by year. Table 1 shows the statistics on annual publications of MOOCs research from the year 2009 to 2020 and indicates a trend of increasing numbers of publications. 2009 marks the first year documents on MOOCs were published and indexed by Scopus, with only three documents 
recorded. From 2009 until 2012, fewer than 20 documents on MOOCs were recorded in the Scopus database. Interestingly, there was a dramatic increase in the number of documents published on MOOCs starting in 2013 with 153 documents published that year. The number gradually increased from the year 2013 until 2018, reflecting the growing interest in MOOCs. Although there were only 298 publications in 2019, this study was conducted just past the midway point of July, 2019. Thus, the full number of documents for the year were yet to be published. In contrast, some journals had already produced their 2020 publications, so these numbers were also recorded by the Scopus database.

Table 1

Number of MOOCs Research Publications by Year

\begin{tabular}{cccc}
\hline Year & Number of documents & Percentage (\%) & Cumulative percentage (\%) \\
\hline 2009 & 3 & 0.10 & 0.10 \\
2010 & 2 & 0.06 & 0.16 \\
2011 & 3 & 0.10 & 0.26 \\
2012 & 11 & 0.35 & 0.61 \\
2013 & 153 & 4.91 & 5.52 \\
2014 & 358 & 11.48 & 17.00 \\
2015 & 494 & 15.84 & 32.84 \\
2016 & 517 & 16.58 & 49.42 \\
2017 & 599 & 19.21 & 68.63 \\
2018 & 678 & 21.74 & 90.38 \\
2019 & 298 & 9.56 & 99.94 \\
2020 & 2 & 0.06 & 100.00 \\
Total & 3,118 & 100.00 & \\
\hline
\end{tabular}

Sources and document types. This study also sought to determine where MOOCs documents had been published by analyzing the data based on document source types. Table 2 shows that journals were the most common source, representing 1,322 (42.40\%) of the total, followed by conference proceedings ( $n=1,199 ; 38.45 \%)$ with a barely $4 \%$ difference only. Trade publications, normally intended for a specific industry, trade, or type of business and usually published in the form of a magazine periodical with the topical subject, were the least frequent document type ( $n=11 ; 0.35 \%)$. Although these trade publications were seldom referred to, they are also scientifically relevant and useful in influencing policies on MOOC implementations.

Table 2

Sources for MOOCs Research

\begin{tabular}{lcc}
\hline \multicolumn{1}{c}{ Source type } & Number of documents & Percentage (\%) \\
\hline Journal & 1,322 & 42.40 \\
Conference proceedings & 1,199 & 38.45 \\
Book series & 361 & 11.58 \\
Book & 225 & 7.22 \\
Trade publication & 11 & 0.35 \\
Total & 3,118 & 100.00 \\
\hline
\end{tabular}


The data were also analyzed based on document types. The Scopus database focuses on primary document types from serial publications, which means that the author is also the researcher in charge of the presented findings. Secondary document types, where the author is different from the person conducting the research, such as book reviews, are not included in Scopus document types. As a result, our analysis revealed the volume of researchers conducting research on MOOCs and their publications.

As shown in Table 3, nearly half of the total publications came from documents presented at a conference or symposium $(n=1,518 ; 48.69 \%)$. This was followed by articles of original research or opinion ( $n=1,146 ; 36.75 \%)$. Book chapters represented $8.11 \%(n=253)$ of the publications on MOOCs. The other types of documents, such as reviews, editorials, letters, notes, books, conference reviews, short surveys, and erratum, each represented less than $2 \%$ of the total publications, respectively.

Table 3

MOOCs Research Document Types

\begin{tabular}{lcc}
\hline \multicolumn{1}{c}{ Document type } & Number of documents & Percentage (\%) \\
\hline Conference paper & 1,518 & 48.69 \\
Article & 1,146 & 36.75 \\
Book chapter & 253 & 8.11 \\
Review & 57 & 1.83 \\
Editorial & 38 & 1.22 \\
Letter & 27 & 0.87 \\
Note & 24 & 0.77 \\
Book & 12 & 0.38 \\
Conference review & 9 & 0.29 \\
Short survey & 8 & 0.26 \\
Erratum & 5 & 0.16 \\
Undefined & 21 & 0.67 \\
Total & 3,118 & 100.00 \\
\hline
\end{tabular}

Source titles. A book series called Lecture Notes in Computer Science Including Subseries Lecture Notes in Artificial Intelligence and Lecture Notes in Bioinformatics contributed the greatest number of publications on MOOCs $(n=183)$. This was followed by the ACM International Conference Proceeding Series $(n=133)$ and CEUR Workshop Proceedings $(n=121)$. The open access International Review of Research in Open and Distributed Learning (IRRODL) proved to be the leading journal of published research related to MOOCs $(n=87)$, followed by the Communications in Computer and Information Science $(n=44)$. Table 4 shows the top 20 sources of publishing on MOOCs.

Table 4

Top 20 Sources for MOOCs Research

\begin{tabular}{lcc}
\hline \multicolumn{1}{c}{ Source title } & $\begin{array}{c}\text { Number of } \\
\text { documents }\end{array}$ & $\begin{array}{c}\text { Percentage } \\
(\%)\end{array}$ \\
\hline Lecture Notes in Computer Science Including Subseries Lecture Notes in & 183 & 5.87 \\
Artificial Intelligence and Lecture Notes in Bioinformatics & & \\
ACM International Conference Proceeding Series & 133 & 4.27 \\
CEUR Workshop Proceedings & 121 & 3.88 \\
International Review of Research in Open and Distributed Learning & 87 & 2.79 \\
\hline
\end{tabular}




\begin{tabular}{lcc}
\hline \multicolumn{1}{c}{ Source title } & $\begin{array}{c}\text { Number of } \\
\text { documents }\end{array}$ & $\begin{array}{c}\text { Percentage } \\
\text { (\%) }\end{array}$ \\
\hline Communications in Computer and Information Science & 44 & 1.41 \\
IEEE Global Engineering Education Conference (EDUCON) & 43 & 1.38 \\
Computers and Education & 34 & 1.09 \\
Journal of Advanced Oxidation Technologies & 31 & 0.99 \\
Proceedings Frontiers in Education Conference (FIE) & 31 & 0.99 \\
Advances in Intelligent Systems and Computing & 30 & 0.96 \\
Lecture Notes in Educational Technology & 28 & 0.90 \\
Proceedings of 2018 Learning with MOOCs (LWMOOCS 2018) & 28 & 0.90 \\
International Journal of Emerging Technologies in Learning & 27 & 0.87 \\
ASEE Annual Conference and Exposition Conference Proceedings & 24 & 0.77 \\
MOOCs and Open Education Around the World & 24 & 0.77 \\
British Journal of Educational Technology & 22 & 0.71 \\
Distance Education & 22 & 0.71 \\
L@s 2016 Proceedings of the 3rd 2016 ACM Conference on Learning at Scale & 22 & 0.71 \\
L@s 2017 Proceedings of the 4th 2017 ACM Conference on Learning at Scale & 22 & 0.71 \\
L@s 2014 Proceedings of the 1st ACM Conference on Learning at Scale & 21 & 0.67 \\
\hline
\end{tabular}

Languages used in documents. Table 5 reveals that English was most common and accounted for $94 \%$ of the 3,118 publications on MOOCs. Spanish was used second most often, but accounted for nearly $3 \%$ only. The rest of documents were published in nine other languages, namely French, Chinese, German, Portuguese, Russian, Hungarian, Japanese, and Korean, but these accounted for less than $0.5 \%$ of the total. While publications on MOOCs appeared in languages other than English, they accounted for only a small percentage. Finally, 35 documents were published in dual languages.

Table 5

Languages Used for MOOCs Research Publications

\begin{tabular}{lcc}
\hline \multicolumn{1}{c}{ Language } & Number of documents & Percentage (\%) \\
\hline English & 2950 & 94.61 \\
Spanish & 92 & 2.95 \\
English; French & 10 & 0.32 \\
English; Italian & 9 & 0.29 \\
French & 9 & 0.29 \\
Chinese & 8 & 0.26 \\
German & 8 & 0.26 \\
Portuguese & 8 & 0.26 \\
English; German & 7 & 0.22 \\
English; Spanish & 5 & 0.16 \\
Russian & 3 & 0.10 \\
English; Chinese & 2 & 0.06 \\
Hungarian & 2 & 0.06 \\
Japanese & 2 & 0.06 \\
English; Portuguese & 1 & 0.03 \\
French; English & 1 & 0.03 \\
Korean & 1 & 0.03 \\
Total & 3,118 & 100.00 \\
\hline
\end{tabular}




\section{Key Areas of MOOCs Research}

The key areas of MOOCs research were analyzed in terms of (a) main subject areas, (b) frequency of keywords, and (c) document titles.

Subject area. This study classified the documents based on their subject area, as presented in Table 6. The data showed that research on MOOCs has emerged in a variety of subject areas. Nearly $60 \%$ of studies involving MOOCs were in the area of computer science, representing $59.33 \%(n=1,850)$ of the total articles, followed by a significant number of publications in the social sciences $(n=1,711$; $54.87 \%)$. The subject areas of engineering, mathematics, decision sciences, business, management and accounting, arts and humanities, and medicine each accounted for more than 100 documents on MOOCs.

Table 6

Subject Areas of MOOCs Research

\begin{tabular}{|c|c|c|}
\hline Subject area & Number of documents & Percentage (\%) \\
\hline Computer science & 1,850 & 59.33 \\
\hline Social sciences & 1,711 & 54.87 \\
\hline Engineering & 517 & 16.58 \\
\hline Mathematics & 331 & 10.62 \\
\hline Decision sciences & 145 & 4.65 \\
\hline Business, management, and accounting & 141 & 4.52 \\
\hline Arts and humanities & 123 & 3.94 \\
\hline Medicine & 101 & 3.24 \\
\hline Psychology & 48 & 1.54 \\
\hline Chemistry & 47 & 1.51 \\
\hline Economics, econometrics, and finance & 44 & 1.41 \\
\hline Physics and astronomy & 33 & 1.06 \\
\hline Materials science & 31 & 0.99 \\
\hline Energy & 29 & 0.93 \\
\hline Agricultural and biological sciences & 24 & 0.77 \\
\hline Environmental science & 23 & 0.74 \\
\hline Nursing & 22 & 0.71 \\
\hline Biochemistry, genetics, and molecular biology & 21 & 0.67 \\
\hline Health professions & 19 & 0.61 \\
\hline Multidisciplinary & 19 & 0.61 \\
\hline Chemical engineering & 11 & 0.35 \\
\hline Neuroscience & 9 & 0.29 \\
\hline Earth and planetary sciences & 8 & 0.26 \\
\hline Pharmacology, toxicology, and pharmaceutics & 8 & 0.26 \\
\hline Veterinary & 5 & 0.16 \\
\hline Immunology and microbiology & 4 & 0.13 \\
\hline Dentistry & 3 & 0.10 \\
\hline
\end{tabular}

Keywords analysis. Figure 1 presents a network visualization of the author keywords that each had a minimum of 10 occurrences. This study used VOSviewer, a software tool for constructing and visualizing bibliometric networks to map authors' keywords. The color, circle size, font size, and thickness of connecting lines represent relationships with other keywords. For example, keywords with the same color were commonly listed together. So, in this study, MOOCs, adaptive learning, blended 
learning, accessibility, SPOC, innovation, LMS, and xMOOC have similar colors, suggesting that these keywords were closely related and usually occurred together (Sweileh et al., 2017).

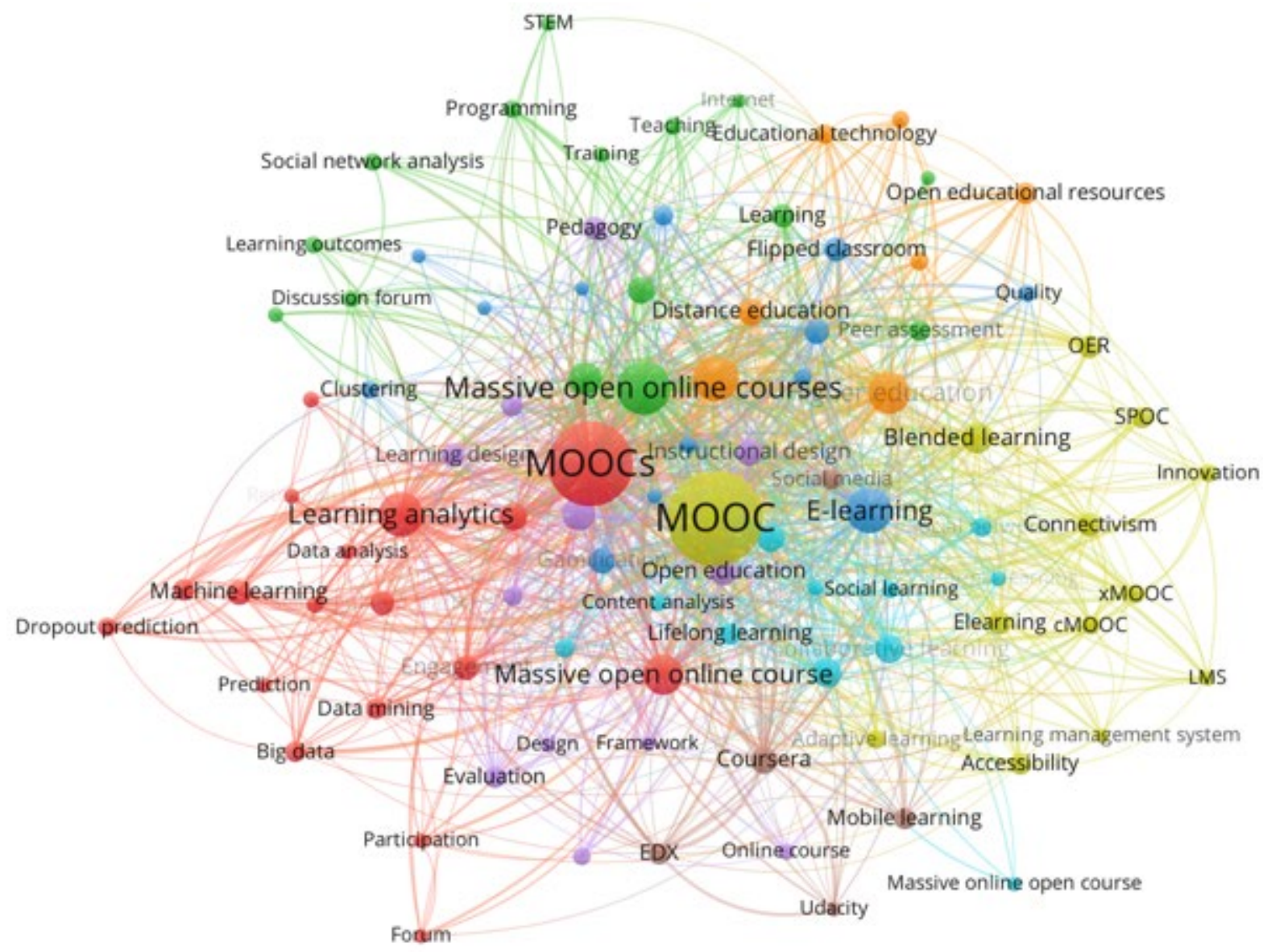

Figure 1. Network visualization map of author keywords with at least 10 occurrences.

Table 7 summarizes the most frequently used keywords in MOOCs studies. After excluding the core keywords related to the search query, the data further revealed that e-learning was the keyword most associated with MOOCs $(n=1,031)$. The keyword "massive open online course" was always used either in full or as an abbreviation (MOOC) and was also presented interchangeably either as a singular term or plural. Other keywords that appeared more than 500 times in documents related to MOOCs were education, teaching, and students. This indicated that MOOCs research was mostly concerned with teaching and learning. Other common keywords appearing more than 100 times were (a) curricula; (b) learning systems; (c) engineering education; (d) online learning; (e) higher education; (f) computeraided instruction; (g) distance education; (h) social networking (online); (i) education computing; ( $\mathrm{j}$ ) learning analytics; (k) data mining; (l) human; (m) surveys; (n) artificial intelligence; and (o) motivation. These keywords were clustered mainly around computer sciences concepts. 
Table 7

Keywords in MOOCs Research and Their Frequency

\begin{tabular}{lcc}
\hline \multicolumn{1}{c}{ Keyword } & Number of documents & Percentage (\%) \\
\hline E-learning & 1,031 & 33.07 \\
Massive open online course & 936 & 30.02 \\
MOOC & 912 & 29.25 \\
Education & 828 & 26.56 \\
Teaching & 704 & 22.58 \\
MOOCs & 658 & 21.10 \\
Students & 506 & 16.23 \\
Curricula & 484 & 15.52 \\
Learning systems & 248 & 7.95 \\
Massive open online courses & 230 & 7.38 \\
Engineering education & 227 & 7.28 \\
Online learning & 204 & 6.54 \\
Higher education & 202 & 6.48 \\
Computer-aided instruction & 194 & 6.22 \\
Distance education & 182 & 5.84 \\
Social networking (online) & 170 & 5.45 \\
Education computing & 169 & 5.42 \\
Learning analytics & 166 & 5.32 \\
Data mining & 130 & 4.17 \\
Human & 120 & 3.85 \\
Surveys & 113 & 3.62 \\
Artificial intelligence & 110 & 3.53 \\
Motivation & 104 & 3.34 \\
\hline
\end{tabular}

Title analysis. Figure 2 shows the visualization of a term co-occurrence network based on title fields with a minimum of 10 occurrences of a term. We used a binary counting method, wherein the number of times a noun phrase occurred in the title of a publication played no role (van Eck \& Waltman, 2014). According to van Eck and Waltman (2014), a noun phrase that occurs only once in the title of a publication is treated in the same way as a noun phrase that occurs, for instance, 10 times. Figure 2 reveals the word "course" was the main term acting as the central node of the whole network (Verk, Golob, \& Podnar, 2019) in MOOCs research. The size of the nodes indicates the weight of the occurrence of the terms, while the thickness of joining lines indicates the strength of the relationship among the terms. Related words, as indicated by the same color, frequently occurred together. For instance, the diagram suggested that (a) application, (b) innovation, (c) construction, (d) flipped classroom, (e) exploration, (f) MOOC environment, (g) library, (h) example, and (i) age (all colored purple) are closely related and usually occurred together. From the titles of the publications in our study, VOSviewer generated eight different colors representing eight clusters with 74 terms. 


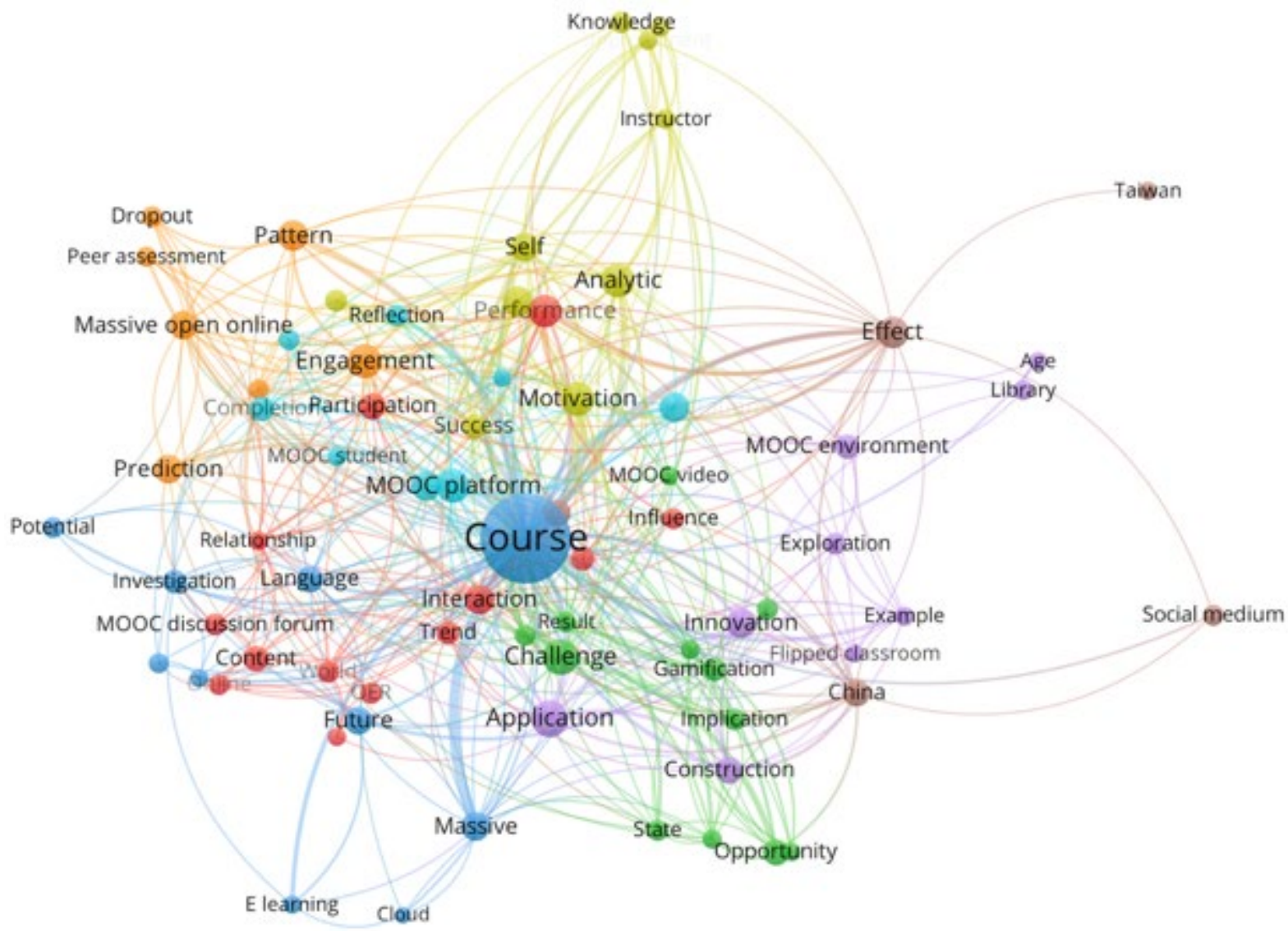

Figure 2. VOSviewer visualization of a term co-occurrence network based on title fields (binary counting).

\section{Major Players and Collaboration in MOOCs Research}

This study examined the characteristics of scientific collaborations on MOOCs research by analyzing (a) the countries that most frequently contributed, (b) the main institutions involved in MOOCs research, (c) authorship analysis, and (d) citations analysis.

Countries contributing most to MOOCs research. Table 8 indicates the top 25 countries from where most MOOCs research originated. The United States (23.03\%) had the leading position, followed by China (14.69\%) and Spain (11.61\%). The remaining distribution of authors' national affiliations represented less than $10 \%$ and was spread across the globe-The United Kingdom, Australia, Germany, the Netherlands, India, Canada, France, Malaysia, Taiwan, Italy, Russian Federation, Ecuador, Switzerland, Mexico, Sweden, Portugal, Greece, Hong Kong, Norway, Austria, Morocco, and Turkey. Clearly, MOOCs play an important role in a wide range of geographic areas. 
Table 8

Geographic Origins of MOOCs Research

\begin{tabular}{lcc}
\hline \multicolumn{1}{c}{ Country } & Number of documents & Percentage (\%) \\
\hline United States & 718 & 23.03 \\
China & 458 & 14.69 \\
Spain & 362 & 11.61 \\
The United Kingdom & 246 & 7.89 \\
Australia & 176 & 5.64 \\
Germany & 127 & 4.07 \\
The Netherlands & 113 & 3.62 \\
India & 107 & 3.43 \\
Canada & 97 & 3.11 \\
France & 88 & 2.82 \\
Malaysia & 69 & 2.21 \\
Taiwan & 60 & 1.92 \\
Italy & 54 & 1.73 \\
Russian Federation & 54 & 1.73 \\
Ecuador & 47 & 1.51 \\
Switzerland & 47 & 1.51 \\
Mexico & 44 & 1.41 \\
Sweden & 42 & 1.35 \\
Portugal & 41 & 1.31 \\
Greece & 39 & 1.25 \\
Hong Kong & 39 & 1.25 \\
Norway & 38 & 1.22 \\
Austria & 36 & 1.15 \\
Morocco & 34 & 1.09 \\
Turkey & 30 & 0.96 \\
\hline & &
\end{tabular}

Main institutions. Table 9 shows the institutions from which most of the publications on MOOCs originated. Out of the 3,118 documents, Universidad Nacional de Educacion a Distancia ( $n=$ 57), which is one of the world's largest universities, located in 13 countries in Europe, America, and Africa, contributed most to publications on MOOCs. This was followed by (a) Universidad Carlos III de Madrid ( $n=47)$; (b) Delft University of Technology $(n=47)$; (c) Massachusetts Institute of Technology (MIT; $n=43$ ); (d) Hasso-Plattner-Institut für Softwaresystemtechnik GmbH ( $n=43)$; and (e) Carnegie Mellon University $(n=42)$. 
Table 9

Institutions Contributing More Than 20 MOOCs Research Documents

\begin{tabular}{lcc}
\hline \multicolumn{1}{c}{ Name of institution } & $\begin{array}{c}\text { Number of } \\
\text { documents }\end{array}$ & Percentage (\%) \\
\hline Universidad Nacional de Educacion a Distancia & 57 & 1.83 \\
Universidad Carlos III de Madrid & 47 & 1.51 \\
Delft University of Technology & 47 & 1.51 \\
Open University & 47 & 1.51 \\
Massachusetts Institute of Technology & 43 & 1.38 \\
Hasso-Plattner-Institut für Softwaresystemtechnik GmbH & 43 & 1.38 \\
Carnegie Mellon University & 42 & 1.35 \\
Pennsylvania State University & 37 & 1.19 \\
Purdue University & 36 & 1.15 \\
Open University of the Netherlands & 36 & 1.15 \\
Universidad Politécnica de Madrid & 34 & 1.09 \\
Stanford University & 33 & 1.06 \\
University of Edinburgh & 33 & 1.06 \\
Harvard University & 31 & 0.99 \\
Tsinghua University & 30 & 0.96 \\
Beijing Normal University & 28 & 0.90 \\
University of Michigan, Ann Arbor & 28 & 0.90 \\
Technische Universität Graz & 27 & 0.87 \\
Swiss Federal Institute of Technology EPFL, Lausanne & 27 & 0.87 \\
Peking University & 25 & 0.80 \\
University of Southampton & 25 & 0.80 \\
Universitat Oberta de Catalunya & 24 & 0.77 \\
Universität Potsdam & 24 & 0.77 \\
Pontificia Universidad Católica de Chile & 24 & 0.77 \\
University of Pittsburgh & 23 & 0.74 \\
Universidad de Salamanca & 23 & 0.74 \\
Universidad Autónoma de Madrid & 23 & 0.74 \\
University of Melbourne & 21 & 0.67 \\
\hline
\end{tabular}

Authorship analysis. Table 10 shows the number of authors per document. From the 3,118 publications considered in this study, 619 (19.85\%) documents were single-authored publications while the remaining had more than one author. Most of the articles on MOOCs were co-authored by two (23.86\%) or three $(23.60 \%)$ authors. There were only two documents co-authored by more than 20 authors. 
Table 10

Number of Authors per Document

\begin{tabular}{lcc}
\hline Author count & Number of documents & Percentage (\%) \\
\hline 1 & 619 & 19.85 \\
2 & 744 & 23.86 \\
3 & 736 & 23.60 \\
4 & 487 & 15.62 \\
5 & 264 & 8.47 \\
6 & 138 & 4.43 \\
7 & 65 & 2.08 \\
8 & 23 & 0.74 \\
9 & 20 & 0.64 \\
10 & 6 & 0.19 \\
11 & 3 & 0.10 \\
12 & 3 & 0.10 \\
13 & 3 & 0.10 \\
14 & 3 & 0.10 \\
15 & 1 & 0.03 \\
17 & 1 & 0.03 \\
21 & 1 & 0.03 \\
26 & 1 & 0.03 \\
Total & 3,118 & 100.00 \\
\hline
\end{tabular}

Table 11 shows the most productive authors who contributed to research on MOOCs. Two authors had the most publications on MOOCs with 35 publications each, namely Carlos Alario-Hoyos, affiliated with Universidad Carlos III de Madrid, Spain, and Christoph Meinel, affiliated with Hasso-Plattner-Institut fur Softwaressystemtechnik GmbH in Potsdam, Germany. The third most productive author publishing on MOOCs was Mar Perez-Sanagustin (23 publications) from Pontificia Universidad Catolica de Chile, in Chile, and also a researcher at the IRIT Institu de Recherche Informatique de Toulouse, France. These three most productive authors in MOOCs studies all came from European countries and all had a computer science background. 
Table 11

Most Productive Authors in MOOCs Research

\begin{tabular}{lcc}
\hline \multicolumn{1}{c}{ Author } & Number of documents & Percentage (\%) \\
\hline Alario-Hoyos, C. & 35 & 1.12 \\
Meinel, C. & 35 & 1.12 \\
Pérez-Sanagustín, M. & 23 & 0.74 \\
Staubitz, T. & 19 & 0.61 \\
Dillenbourg, P. & 17 & 0.55 \\
Reich, J. & 17 & 0.55 \\
Chen, L. & 16 & 0.51 \\
Khalil, M. & 16 & 0.51 \\
Zheng, Q. & 16 & 0.51 \\
Brooks, C. & 15 & 0.48 \\
Kalz, M. & 15 & 0.48 \\
Kloos, C. D. & 15 & 0.48 \\
Muñoz-Merino, P. J. & 15 & 0.48 \\
Renz, J. & 15 & 0.48 \\
Rosé, C. P. & 15 & 0.48 \\
Watson, S. L. & 15 & 0.48 \\
Burgos, D. & 14 & 0.45 \\
Davis, D. & 14 & 0.45 \\
Ebner, M. & 14 & 0.45 \\
García-Peñalvo, F. J. & 14 & 0.45 \\
\hline
\end{tabular}

VOSviewer software was used to present a network visualization (see Figure 3) of the mapping of coauthorship among different authors. This mapping used the fractional counting method and was based on data of those authors who had at least five documents on MOOCs and at least five citations. The color, circle size, font size, and thickness of connecting lines indicate the strength of the relationship among the authors. Related authors, as indicated by the same color, are commonly listed together. For example, the diagram suggests that Meinel, C., Staubitz, T., and Renz, J., who are all from the same institution in Germany, have collaborated closely. From the analysis, Alario-Hoyos seems to have had a strong collaboration with authors from different parts of the world including Chile, Portugal, Guatemala, Malaysia, and the U.K. 

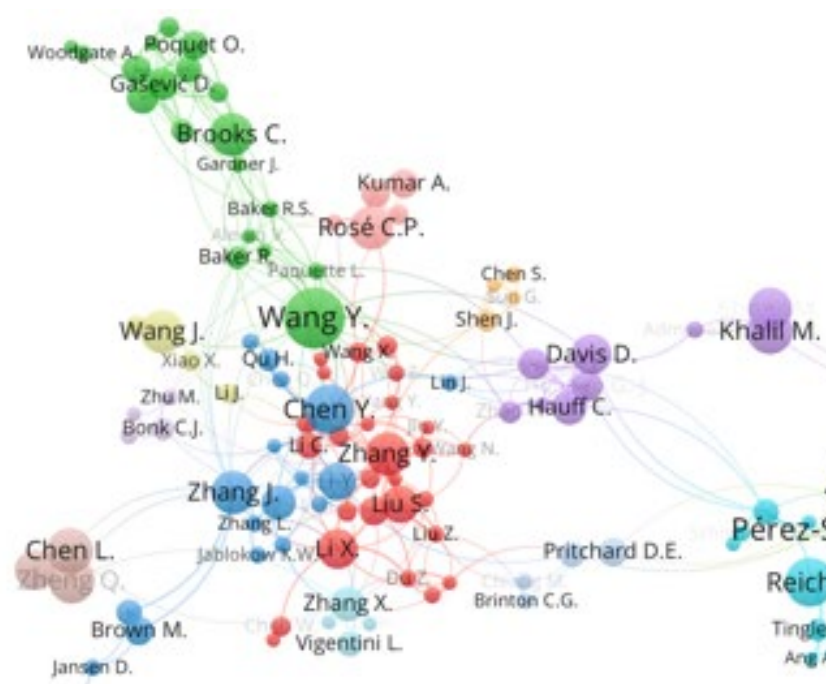

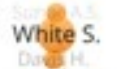

Dickensk Chaog v.

Coloardeni R.H. Garcia-Peñalvo F.J.
Fidalgo-Blanco A.

\section{Staubitz T.}

Meinel C.

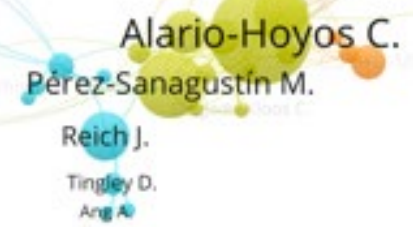

Figure 3. Network visualization map of MOOCs research co-authors.

Figure 4 further shows the network visualization map of the authors based on the countries they are affiliated with. Only countries with at least five documents and at least five citations were considered in this analysis. Based on the fractional counting method, it was clear that authors from the United States have played a prominent role in collaborating with authors from other countries in terms of MOOCs research. Authors from The United States have worked closely with colleagues from (a) Malaysia, (b) Saudi Arabia, (c) Japan, (d) Ireland, and (e) Singapore. Several collaborative efforts with colleagues in other countries have also been established by authors from Spain, The United Kingdom, Germany, and the Netherlands. 


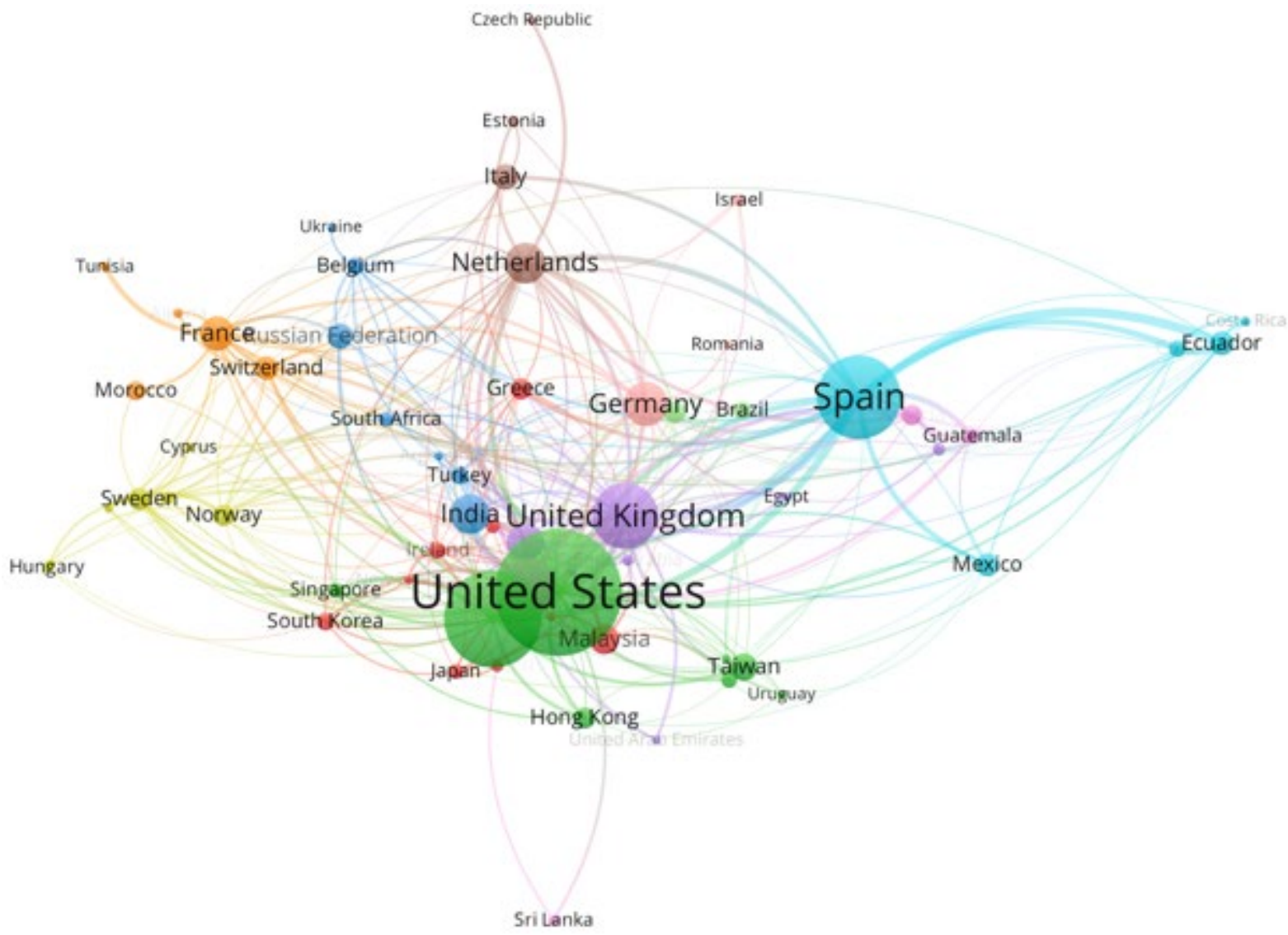

Figure 4. Network visualization map of MOOCs research co-authors by country.

Citation analysis. Table 12 reports the citation metric of the papers obtained from the Scopus database. There were 19,862 citations reported in 10 years (2009-2019) for 3,118 articles, with an average of 1,986 citations per year.

Table 12

MOOCs Research Citation Metrics

\begin{tabular}{lr}
\hline \multicolumn{1}{c}{ Metric } & \multicolumn{1}{c}{ Data } \\
\hline Total papers & 3,118 \\
Total citations & 19,862 \\
Number of years & 10 \\
Citations per year & $1,986.2$ \\
Citations per paper & 6.37 \\
Citations per author & $9,322.76$ \\
Papers per author & $1,432.02$ \\
Authors per paper & 3.02 \\
h-index & 59 \\
g-index & 93 \\
\hline
\end{tabular}

Table 13 summarizes the 20 documents on MOOCs most often cited, based on the number of times each was cited. The two documents most often cited were the systematic study on MOOCs conducted by Liyanagunawardena et al. (2013) in the early days of MOOC expansion, as well as another empirical 
study on how MOOC videos affected student engagement by Guo, Kim, and Rubin (2014). Other documents most often cited were literature reviews or those that addressed the issues of (a) learner disengagement, (b) enrolment and completion, (c) challenges, (d) quality, (e) motivation, and (f) pedagogy.

Table 13

Most Influential Documents: Those With a Minimum of 100 Citations per Document

\begin{tabular}{|c|c|c|c|c|c|}
\hline Author (year) & Title & Source & $\mathrm{TC}$ & CPY & CPA \\
\hline $\begin{array}{l}\text { Liyanagunawardena, } \\
\text { Adams, \& Williams } \\
\text { (2013) }\end{array}$ & $\begin{array}{l}\text { MOOCs: A } \\
\text { systematic study of } \\
\text { the published } \\
\text { literature 2008- } \\
2012\end{array}$ & $\begin{array}{l}\text { International } \\
\text { Review of Research } \\
\text { in Open and } \\
\text { Distributed Learning }\end{array}$ & 422 & 70.33 & 141 \\
\hline $\begin{array}{l}\text { Guo, Kim, \& Rubin } \\
\text { (2014) }\end{array}$ & $\begin{array}{l}\text { How video } \\
\text { production affects } \\
\text { student engagement: } \\
\text { An empirical study of } \\
\text { MOOC videos }\end{array}$ & $\begin{array}{l}1^{\text {st }} \text { ACM Conference } \\
\text { on Learning at Scale, } \\
L @ S 2014\end{array}$ & 422 & 84.40 & 141 \\
\hline $\begin{array}{l}\text { Kizilcec, Piech, \& } \\
\text { Schneider (2013) }\end{array}$ & $\begin{array}{l}\text { Deconstructing } \\
\text { disengagement: } \\
\text { Analyzing learner } \\
\text { subpopulations in } \\
\text { massive open online } \\
\text { courses }\end{array}$ & $\begin{array}{l}3^{\text {rd }} \text { International } \\
\text { Conference on } \\
\text { Learning Analytics } \\
\text { and Knowledge, LAK } \\
2013\end{array}$ & 383 & 63.83 & 128 \\
\hline Jordan (2014) & $\begin{array}{l}\text { Initial trends in } \\
\text { enrolment and } \\
\text { completion of } \\
\text { massive open online } \\
\text { courses }\end{array}$ & $\begin{array}{l}\text { International } \\
\text { Review of Research } \\
\text { in Open and } \\
\text { Distributed Learning }\end{array}$ & 299 & 59.80 & 299 \\
\hline Kop (2011) & $\begin{array}{l}\text { The challenges to } \\
\text { connectivist learning } \\
\text { on open online } \\
\text { networks: Learning } \\
\text { experiences during a } \\
\text { massive open online } \\
\text { course }\end{array}$ & $\begin{array}{l}\text { International } \\
\text { Review of Research } \\
\text { in Open and } \\
\text { Distributed Learning }\end{array}$ & 243 & 30.38 & 243 \\
\hline $\begin{array}{l}\text { Margaryan, Bianco, } \\
\text { \& Littlejohn (2015) }\end{array}$ & $\begin{array}{l}\text { Instructional quality } \\
\text { of massive open } \\
\text { online courses } \\
\text { (MOOCs) }\end{array}$ & $\begin{array}{l}\text { Computers and } \\
\text { Education }\end{array}$ & 227 & 56.75 & 76 \\
\hline $\begin{array}{l}\text { Hew \& Cheung } \\
\text { (2014) }\end{array}$ & $\begin{array}{l}\text { Students' and } \\
\text { instructors' use of } \\
\text { massive open online } \\
\text { courses (MOOCs): } \\
\text { Motivations and } \\
\text { challenges }\end{array}$ & $\begin{array}{l}\text { Educational } \\
\text { Research Review }\end{array}$ & 227 & 45.40 & 114 \\
\hline
\end{tabular}




\begin{tabular}{|c|c|c|c|c|c|}
\hline Author (year) & Title & Source & $\mathrm{TC}$ & CPY & $\mathrm{CPA}$ \\
\hline $\begin{array}{l}\text { Kop, Fournier, \& } \\
\text { Mak (2011) }\end{array}$ & $\begin{array}{l}\text { A pedagogy of } \\
\text { abundance or a } \\
\text { pedagogy to support } \\
\text { human beings? } \\
\text { Participant support } \\
\text { on massive open } \\
\text { online courses }\end{array}$ & $\begin{array}{l}\text { International } \\
\text { Review of Research } \\
\text { in Open and } \\
\text { Distributed Learning }\end{array}$ & 200 & 25.00 & 67 \\
\hline Clow (2013) & $\begin{array}{l}\text { MOOCs and the } \\
\text { funnel of } \\
\text { participation }\end{array}$ & $\begin{array}{l}3^{\text {rd }} \text { International } \\
\text { Conference on } \\
\text { Learning Analytics } \\
\text { and Knowledge, LAK } \\
2013\end{array}$ & 190 & 31.67 & 190 \\
\hline Martin (2012) & $\begin{array}{l}\text { Will massive open } \\
\text { online courses } \\
\text { change how we } \\
\text { teach? }\end{array}$ & $\begin{array}{l}\text { Communications of } \\
\text { the ACM }\end{array}$ & 176 & 25.14 & 176 \\
\hline Fini (2009) & $\begin{array}{l}\text { The technological } \\
\text { dimension of a } \\
\text { massive open online } \\
\text { course: The case of } \\
\text { the CCKo8 course } \\
\text { tools }\end{array}$ & $\begin{array}{l}\text { International } \\
\text { Review of Research } \\
\text { in Open and } \\
\text { Distributed Learning }\end{array}$ & 173 & $17 \cdot 30$ & 173 \\
\hline Fox (2013) & $\begin{array}{l}\text { From MOOCs to } \\
\text { SPOCs }\end{array}$ & $\begin{array}{l}\text { Communications of } \\
\text { the ACM }\end{array}$ & 136 & 22.67 & 136 \\
\hline $\begin{array}{l}\text { Alraimi, Zo, \& } \\
\text { Ciganek (2015) }\end{array}$ & $\begin{array}{l}\text { Understanding the } \\
\text { MOOCs continuance: } \\
\text { The role of openness } \\
\text { and reputation }\end{array}$ & $\begin{array}{l}\text { Computers and } \\
\text { Education }\end{array}$ & 124 & 31.00 & 41 \\
\hline $\begin{array}{l}\text { DeBoer, Ho, Stump, } \\
\text { \& Breslow (2014) }\end{array}$ & $\begin{array}{l}\text { Changing "course": } \\
\text { Reconceptualizing } \\
\text { educational variables } \\
\text { for massive open } \\
\text { online courses }\end{array}$ & $\begin{array}{l}\text { Educational } \\
\text { Researcher }\end{array}$ & 118 & 23.60 & 30 \\
\hline Reich (2015) & $\begin{array}{l}\text { Rebooting MOOC } \\
\text { research }\end{array}$ & Science & 113 & 28.25 & 113 \\
\hline $\begin{array}{l}\text { DeWaard, et al. } \\
\text { (2011) }\end{array}$ & $\begin{array}{l}\text { Using mLearning } \\
\text { and MOOCs to } \\
\text { understand chaos, } \\
\text { emergence, and } \\
\text { complexity in } \\
\text { education }\end{array}$ & $\begin{array}{l}\text { International } \\
\text { Review of Research } \\
\text { in Open and } \\
\text { Distributed Learning }\end{array}$ & 112 & 14.00 & 16 \\
\hline $\begin{array}{l}\text { Daradoumis, Bassi, } \\
\text { Xhafa, \& Caballé } \\
\text { (2013) }\end{array}$ & $\begin{array}{l}\text { A review on massive } \\
\text { e-learning (MOOC) } \\
\text { design, delivery and } \\
\text { assessment }\end{array}$ & $\begin{array}{l}20138^{\text {th }} \\
\text { International } \\
\text { Conference on P2P, } \\
\text { Parallel, Grid, Cloud } \\
\text { and Internet }\end{array}$ & 108 & 18.00 & 27 \\
\hline
\end{tabular}




\begin{tabular}{|c|c|c|c|c|c|}
\hline Author (year) & Title & Source & $\mathrm{TC}$ & CPY & CPA \\
\hline & & $\begin{array}{l}\text { Computing, 3PGCIC } \\
2013\end{array}$ & & & \\
\hline $\begin{array}{l}\text { Kay, Reimann, } \\
\text { Diebold, \& } \\
\text { Kummerfeld (2013) }\end{array}$ & $\begin{array}{l}\text { MOOCs: So many } \\
\text { learners, so much } \\
\text { potential. }\end{array}$ & $\begin{array}{l}\text { IEEE Intelligent } \\
\text { Systems }\end{array}$ & 107 & 17.83 & 27 \\
\hline $\begin{array}{l}\text { Gasevic, Kovanovic, } \\
\text { Joksimovic, \& } \\
\text { Siemens (2014) }\end{array}$ & $\begin{array}{l}\text { Where is research on } \\
\text { massive open online } \\
\text { courses headed? A } \\
\text { data analysis of the } \\
\text { MOOC Research } \\
\text { Initiative }\end{array}$ & $\begin{array}{l}\text { International } \\
\text { Review of Research } \\
\text { in Open and } \\
\text { Distributed Learning }\end{array}$ & 105 & 21.00 & 26 \\
\hline $\begin{array}{l}\text { Zheng, Rosson, Shih, } \\
\text { \& Carroll (2015) }\end{array}$ & $\begin{array}{l}\text { Understanding } \\
\text { student motivation, } \\
\text { behaviors, and } \\
\text { perceptions in } \\
\text { MOOCs }\end{array}$ & $\begin{array}{l}18^{\text {th }} \text { ACM } \\
\text { International } \\
\text { Conference on } \\
\text { Computer- } \\
\text { Supported } \\
\text { Cooperative Work } \\
\text { and Social } \\
\text { Computing, CSCW } \\
2015\end{array}$ & 101 & 25.25 & 25 \\
\hline
\end{tabular}

Notes. $\mathrm{TC}=$ total citations; $\mathrm{CPY}=$ citations per year; $\mathrm{CPA}=$ citations per author.

Figure 5 presents the mapping of citations for documents with a minimum of 20 citations. It illustrates the key authors in the field and how their ideas were situated in relation to each other. Countries of origin are further reflected in Figure 6. The United States, Spain, and China appeared to be the most influential countries, as this was where the MOOCs research authors most often cited were based. 


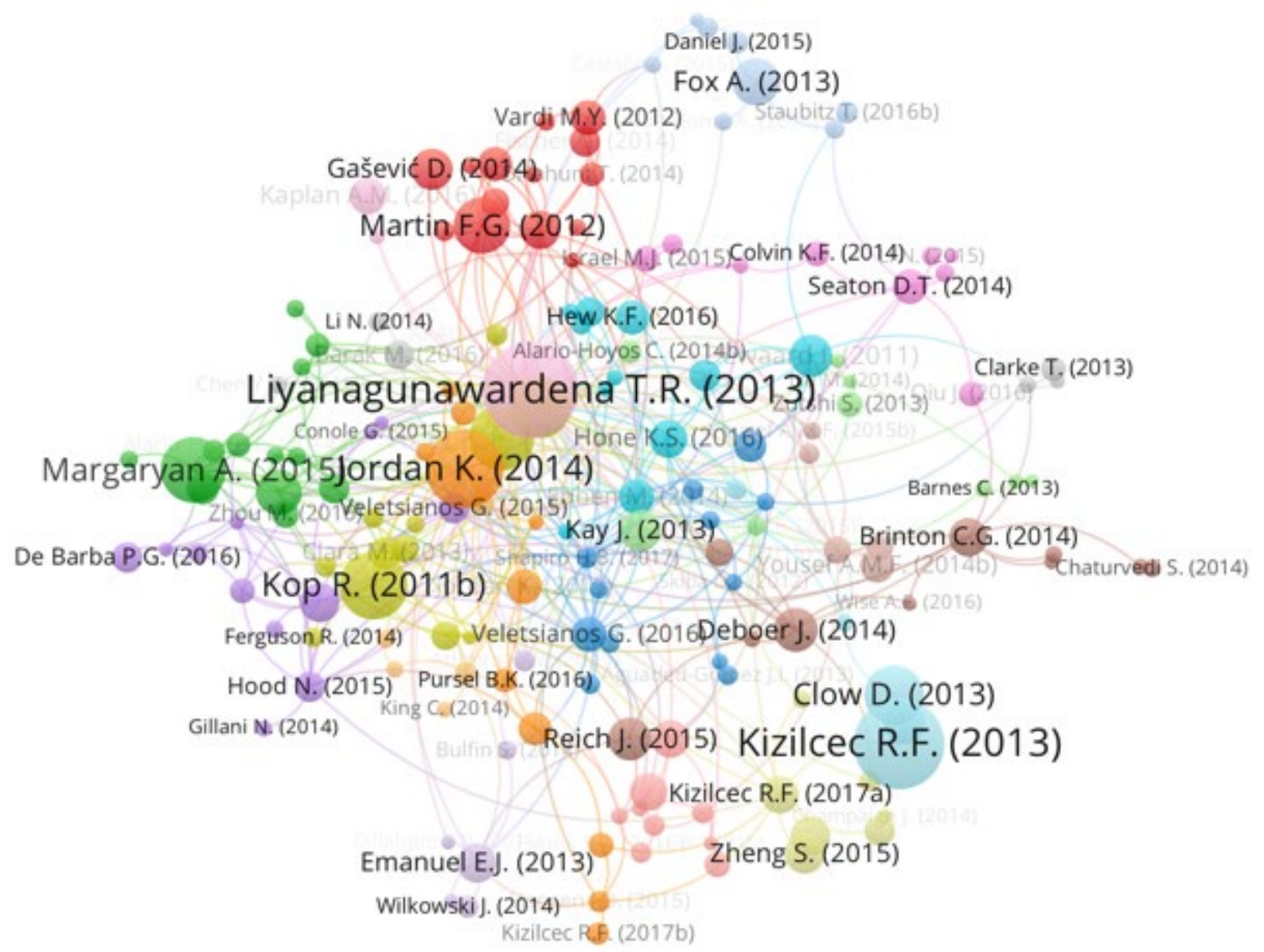

Figure 5. Network visualization map of citations of MOOC documents. 


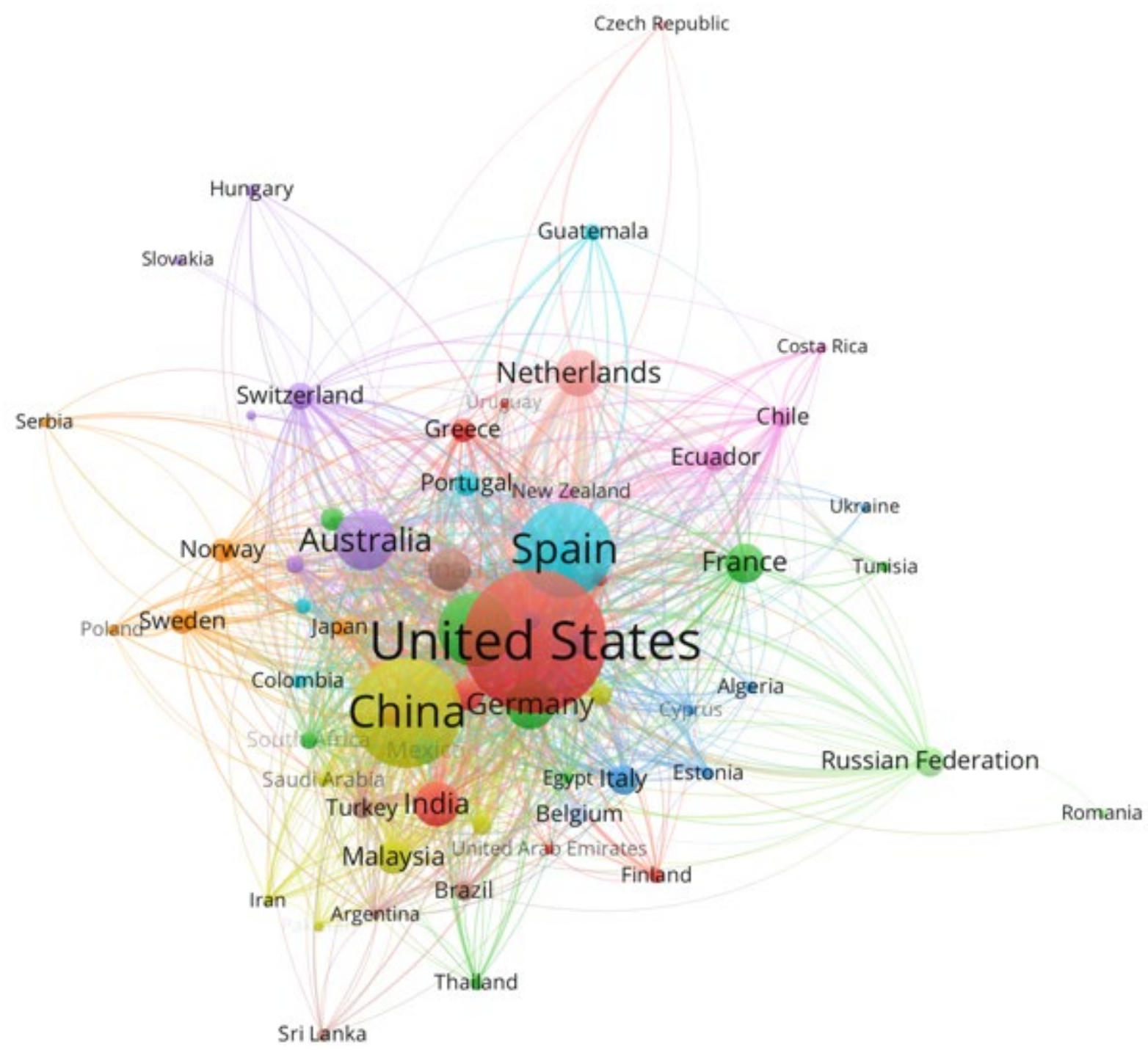

Figure 6. Network visualization map of citations of MOOCs documents by country, with a minimum of five documents per country and a minimum of five citations per country.

\section{Discussion}

This study was motivated by two observations. First, MOOCs have been regarded as a tool that contributes towards the universal agenda of addressing the digital divide and promoting equity in educational opportunities (Ma \& Lee, 2019), as also stipulated in the Sustainable Development Goal 4 (United Nations General Assembly, 2015). Second, MOOCs have also been suggested as a strategy for the internationalization of higher education institutions (Kerr \& Reda, 2019). However, questions have been raised as to whether research on MOOCs is interdisciplinary and conducted collaboratively across different parts of the world. Consultation with people from different local contexts and backgrounds represents inclusiveness, which is important in creating MOOCs (King, Pegrum, \& Forsey, 2018). To address this issue, we conducted a bibliometric analysis of 3,118 items of MOOCs literature published during a period of 10 years (from 2009 to July 17, 2019), collected from the Scopus database. We 
considered three main research questions: (a) how has MOOCs research evolved and been distributed, (b) what key topic areas have been discussed in MOOCs research, and (c) who are the major players in MOOCs research and how have they collaborated. These three questions were analyzed according to different main themes.

With respect to the first research question on the evolution and distribution of MOOCs research, our findings showed that documents on MOOCs appeared in early 2009 shortly after the MOOC acronym was first coined by Dave Cormier and Brian Alexander in 2008 (Zancanaro \& Domingues, 2017) and the number grew steadily for the 10 years that followed. The earliest documents on MOOCs were published in two different conference proceedings by two groups of authors, both from Sichuan, China, while another document was from an Italian author, published in the International Review of Research in Open and Distributed Learning. This shows that in their early development, MOOCs had been noticed by scholars from the East as well as the West. There was slow development within the four years after MOOCs were introduced (2009-2012). A significant change took place in 2013 when a sudden surge of documents was published, perhaps because MOOCs had received considerable media coverage driven by service providers such as Udacity, Coursera, and edX (Jansen, Schuwer, Teixeira, \& Aydin, 2015). The number of documents grew consistently from 2013 to 2019, reflecting increasing interest in, as well as relevance and importance of MOOCs. This finding was compatible with the studies reported by Liyanagunawardena et al. (2013) and Zancanaro, Todesco, and Ramos (2015). Most research on MOOCs was found in journals and conference proceedings in the form of articles and conference papers. The documents most often appeared in titles meant for those working in the area of computer science, information systems, or information technology, and based in the U.S. and central Europe. In addition, most MOOCs documents were published in English, despite flourishing MOOCs delivered in different languages (Lambert, 2020). This suggests that the research has paid less attention to MOOCs as encouraging inclusiveness, and has undervalued their important role in promoting part of the United Nation universal agenda, particularly to achieve Sustainable Development Goal 4 in ensuring inclusive and equitable quality education for all by 2030. The underlying implication is that despite the thriving research on MOOCs, it has aimed mainly at a small, focused group. Potential stakeholders from different areas are missing out on the potential of MOOCs, as well as the latest developments, recommendations, and effects.

Regarding the second research question, our observations on subject areas, keywords, and titles suggested that MOOCs research has been confined mainly within the domain of computer science and the social sciences area, particularly as these relate to education. The clustering of MOOCs research in just two main subject areas is further evident by the keywords most frequently used. These indicated that most MOOCs studies were concerned with (a) education, (b) teaching, (c) students, (d) curricula, (e) learning systems, (f) engineering education, (g) online learning, and (h) higher education. This somewhat differs from Ebben and Murphy (2014), who showed that journals publishing MOOCs research lacked penetration into the traditional fields of study such as the humanities, sciences, and social sciences. Perhaps online and distance education journals, and those in computer science, have speedier publication processes due to rapid changes in their subject matter (Ebben \& Murphy, 2014). The narrow disciplinary fragmentation may also due to the complexities of (a) carrying out MOOCs research, (b) framing diverse problems, and (c) aspiring for collaboration (Cairns, Hielscher, \& Light, 2020). Therefore, it is important for future research on MOOCs to expand beyond the fields of distance education and computer science into different discipline-based and interdisciplinary research. For instance, a study on employer receptivity to using MOOCs in recruiting, hiring, and professional 
development (Radford et al., 2014) could create more awareness and use of MOOCs by various bodies or organizations. The expansion of subject matter, key areas, or large-scale field trials in MOOCs research may also help address the problem of abysmal completion rates in MOOCs, and focus on finding what works, where, and for whom (Kizilcec et al., 2020).

As regards the third research question, there seemed to be a reasonable amount of scientific collaboration on MOOCs research across the globe as reflected in our analysis of countries, institutions, authors, and citations. Although MOOCs initially began in Canada, the United States, China, and Spain were the top three countries from which scholarly writings on MOOCs have been published. This finding supports previous studies that found most publications on MOOCs, as well as the vast majority of MOOCs participants, were from North America and Europe (Lambert, 2020; Zancanaro \& Domingues, 2018; Zhu et al., 2018a). The U.S. had the highest number of publications on MOOCs, which indicated that it was leading in MOOCs research and, potentially, had directed funding to it. This may be corroborated further by the fact that the U.S. has by far the most top-ranked universities in the world. The U.S., thus, has been in a much stronger position to bring the best possible content from the best schools and best professors to everyone with online access. In addition, most service providers and platforms for MOOCs originated in the U.S. and Europe, and various initiatives such as European OpenupEd supported the proliferation of MOOCs there. The big gap between MOOCs that originated from these countries compared to the rest of the world should be a point of concern, since one of the major goals of MOOCs is to promote inclusivity and equitable educational opportunities that are suitable in all contexts, not only in the U.S. or Europe. Factors such as technology infrastructure (Yousef, Chatti, Schroeder, Wosnitza, \& Jakobs, 2014), access to the Internet, and participant literacies that are lacking in other institutions may be some of the factors that have discouraged the research on MOOCs in different countries. The implication of the lack of evidence-based research on non-mainstream consumers could potentially reflect a cultural hegemony that promotes Western values, language, and knowledge systems (Deng, Benckendorff, \& Gannaway, 2019). Hence, it is crucial that future research on MOOCs promotes the understanding of different cultural contexts (Gameel \& Wilkins, 2019), social needs, and economic development. This will help shape MOOCs that can respond better to different industries, participants, and characteristics across countries (Li, 2017).

Further analysis implies that MOOCs research was mostly collaborative, which is an opportunity for MOOCs studies. Co-authorship represents a valid proxy for collaboration, and it can be assumed that sharing authorship reflected a tangible engagement (Adam, 2013). This study revealed a broad spectrum of cooperation on MOOCs research among scholars, institutions, and countries. Confirming Zhu et al. (2018a) that most collaborations are within an institution and only a small percentage are international, this study revealed healthy cross-country collaboration, though proximity played a role in forging such collaboration. There was little collaboration in MOOCs research across Europe, the U.S., South America, and Asia. This may result in fragmented understanding of MOOCs, confined to geographical, economic, institutional, and cultural circumstances, despite the potential of MOOCs to penetrate across boundaries.

Probing the most often cited documents, those from the U.S., China, and Spain were cited most, but our findings also pointed towards a healthy citation impact from different countries around the globe. Citations of documents from multiple countries implies that authors recognize their scientific community in different geographical areas, which may contribute to forming scientific paradigms (Pan, Kaski, \& Fortunato, 2012). Compared to the U.S., China seemed to have had more recognition in terms 
of citations from central Asia, which coincided with China's aspirations, since the end of the Cold War, to influence this part of the world (Rogers, 2007).

Collaboration is important so that MOOCs may adapt to local contexts (Ichou, 2018) and provide strategic insights into how best to design, manage, and implement MOOCs. Through collaboration, knowledge may be better transferred, combined, and reinforced. Countries can learn from each other's experiences in order to enhance MOOCs potential to encourage knowledge sharing across organizational boundaries. Connections with leading universities and prominent scholars in the area also promote academic reputations and serve to improve the visibility of publications. The transfer and reinforcement of knowledge are closely associated with the spillover of knowledge, which can be key to the successful implementation of MOOCs. It is, however, unclear to what extent collaboration on MOOCs research exists between universities in less developed regions. Collaborations among countries, institutions, and scholars are often associated with the transfer of knowledge and technology, which is extremely important for the world's economies. It is interesting to see how such collaborations monitor and manage the intellectual property aspects that have become critical to controlling original innovations. Views on the danger of MOOCs in reinforcing inequalities in education (Rohs \& Ganz, 2015) and MOOCs that help distribute free education (Lambert, 2020) might also be addressed by forging more collaborations with different stakeholders. This effort will serve to encourage inclusive and equal access to education.

\section{Conclusion}

This study used bibliometric analysis to undertake a comprehensive overview of the publications relating to research about MOOCs or massive open online courses from 2009 to 2020. Mapping the evolution of MOOCs, key topic areas, and collaborations within a series of categories (i.e., number of published studies per year, sources, languages, subject areas, keywords, document titles, contributing countries, main institutions, authorship, and citations), indicated broad applications of the MOOCs format. Findings showed that early research on MOOCs was carried out by scholars from both the East and the West, and has continuously grown and been widely disseminated since then. Nevertheless, most MOOCs research has focused mainly on the same limited fields of computer science and distance education that dealt with topics connected to the social sciences discipline. This has led to disengagement from other disciplines and reduced the emergence of new ideas and innovation. There has been increasing collaboration on MOOCs research among scholars or institutions from a limited group of countries, implying a lack of perspectives from different economic, cultural, and institutional backgrounds. This evolution of MOOCs in general reflects a rising emphasis on open online courses conducted at a global level, thereby addressing the criticism that MOOCs are decreasing. In addition, collaborations and communications involving MOOCs research, which greatly influence educational decisions and perspectives, are confined mainly to certain geographical areas, and do not represent countries in the greatest need for the benefits of MOOCs. A sizeable increase in investment and dedicated funding to encourage stronger international participation from lesser developed nations will be valuable, and is recommended, to ensure that opportunities in MOOCs may be equally enjoyed and appreciated.

It must be acknowledged that this study relied solely on the Scopus database and on the choice of keywords used in document titles. We did not consider other rich databases such as Google Scholar or 
documents that discussed MOOCs but may have had titles outside our search parameters. Extending the procedures for text analysis to also include abstracts would likely reveal additional information and frequencies. In addition, some authors or institutions might have registered more than one name into Scopus or provided different spellings, and this may have resulted in inaccurate details on authors' affiliations or productivity.

Despite these limitations, this study contributes to a better understanding of the trends in MOOCs research and publications. Each of the indicators points towards growth in this field of research which may offer more opportunities for bettering current educational systems. This study extends and complements previous findings on MOOCs literature by using bibliometric methods. The current analysis produces several exciting observations that clearly highlight the rising importance of MOOCs in the educational environment around the world, as well as their dissemination, and the need for more research involving cooperation among various regions and different fields. More studies are needed to explore and help balance the education gap that may arise in the context of MOOCs development. Focusing efforts on cultural differences in MOOCs is one likely topic to be pursued. This will facilitate the attainment of educational goals worldwide and ensure that everyone may benefit from MOOCs.

\section{Acknowledgements}

This work was supported in part by the Ministry of Education Malaysia, under the Malaysian Fundamental Research Grant Scheme [S/O Code 13049]. 


\section{References}

Adams, J. (2013). The fourth age of research. Nature, 497, 557-560. https://doi.org/10.1038/497557a

Alraimi, K. M., Zo, H., \& Ciganek, A. P. (2015). Understanding the MOOCs continuance: The role of openness and reputation. Computers \& Education, 80 , 28-38.

https://doi.org/10.1016/j.compedu.2014.08.006

Baggaley, J. (2013). MOOC rampant. Distance Education, 34(3), 368-378.

https://doi.org/10.1080/01587919.2013.835768

Cairns, R., Hielscher, S., \& Light, A. (2020). Collaboration, creativity, conflict and chaos: Doing interdisciplinary sustainability research. Sustainability Science, 1-11.

https://doi.org/10.1007/s11625-020-00784-z

Clow, D. (2013). MOOCs and the funnel of participation. Proceedings of the Third International Conference on Learning Analytics and Knowledge, 185-189.

https://doi.org/10.1145/2460296.2460332

Daradoumis, T., Bassi, R., Xhafa, F., \& Caballé, S. (2013). A review on massive e-learning (MOOC) design, delivery and assessment. 2013 Eighth International Conference on P2P, Parallel, Grid, Cloud and Internet Computing, 208-213. https://doi.org/10.1109/3pgcic.2013.37

DeBoer, J., Ho, A. D., Stump, G. S., \& Breslow, L. (2014). Changing "course": Reconceptualizing educational variables for massive open online courses. Educational Researcher, 43(2), 74-84. https://doi.org/10.3102/0013189x14523038

Deng, R., \& Benckendorff, P. (2017). A contemporary review of research method adopted to understand students' and instructors' use of massive open online courses (MOOCs). International Journal of Information and Education Technology, 7(8), 601-607. https://doi.org/10.18178/ijiet.2017.7.8.939

Deng, R., Benckendorff, P., \& Gannaway, D. (2019). Progress and new directions for teaching and learning in MOOCs. Computers and Education, 129, 48-60. https://doi.org/10.1016/j.compedu.2018.10.019

De Waard, I., Abajian, S., Gallagher, M. S., Hogue, R., Keskin, N., Koutropoulos, A., \& Rodriguez, O. C. (2011). Using mLearning and MOOCs to understand chaos, emergence, and complexity in education. The International Review of Research in Open and Distributed Learning, 12(7), 94-115. https://doi.org/10.19173/irrodl.v12i7.1046

Ebben, M., \& Murphy, J. S. (2014). Unpacking MOOC scholarly discourse: A review of nascent MOOC scholarship. Learning, Media and Technology, 39(3), 328-345. https://doi.org/10.1080/17439884.2013.878352

Fini, A. (2009). The technological dimension of a massive open online course: The case of the CCKo8 course tools. The International Review of Research in Open and Distributed Learning, 10(5). https://doi.org/10.19173/irrodl.v10i5.643 
Fox, A. (2013). From MOOCs to SPOCs. Communications of the ACM, 56(12), 38-40. https://doi.org/10.1145/2535918

Gameel, B. G., \& Wilkins, K. G. (2019). When it comes to MOOCs, where you are from makes a difference. Computers \& Education, 136, 49-60. https://doi.org/10.1016/J.COMPEDU.2019.02.014

Gašević, D., Kovanović, V., Joksimović, S., \& Siemens, G. (2014). Where is research on massive open online courses headed? A data analysis of the MOOC Research Initiative. International Review of Research in Open and Distributed Learning, 15(5), 134-176. https://doi.org/10.19173/irrodl.v15i5.1954

Guo, P. J., Kim, J., \& Rubin, R. (2014). How video production affects student engagement: An empirical study of MOOC videos. Proceedings of the First ACM Conference on Learning@ scale conference, 41-50. https://doi.org/10.1145/2556325.2566239

Hew, K. F., \& Cheung, W. S. (2014). Students' and instructors' use of massive open online courses (MOOCs): Motivations and challenges. Educational Research Review, 12, 45-58. https://doi.org/10.1016/j.edurev.2014.05.001

Ichimura, Y., \& Suzuki, K. (2017). Dimensions of MOOCs for quality design: Analysis and synthesis of the literature. International Journal for Educational Media and Technology, 11(1), 42-49. https://pdfs.semanticscholar.org/4558/8b442b1f8bccef408a63ef6114ed643b2ab7.pdf

Ichou, R. P. (2018). Can MOOCs reduce global inequality in education? Australasian Marketing Journal, 26(2), 116-120. https://doi.org/10.1016/j.ausmj.2018.05.007

Jansen, D., Schuwer, R., Teixeira, A., \& Aydin, C. H. (2015). Comparing MOOC adoption strategies in Europe: Results from the HOME project survey. International Review of Research in Open and Distributed Learning, 16(6), 116-136. https://doi.org/10.19173/irrodl.v16i6.2154

Jiang, S., Williams, A. E., Warschauer, M., He, W., \& O’Dowd, D. K. (2014). Influence of incentives on performance in a pre-college biology MOOC. International Review of Research in Open and Distributed Learning, 15(5), 99-112. https://doi.org/10.19173/irrodl.v15i5.1858

Jordan, K. (2014). Initial trends in enrolment and completion of massive open online courses. The International Review of Research in Open and Distributed Learning, 15(1). https://doi.org/10.19173/irrodl.v1511.1651

Kay, J., Reimann, P., Diebold, E., \& Kummerfeld, B. (2013). MOOCs: So many learners, so much potential. IEEE Intelligent Systems, 28(3), 70-77. https://doi.org/10.1109/mis.2013.66

Kerr, R., \& Reda, V. (2019). MOOCs as institutional internationalization strategy: First Italian courses on edX platform. EMOOCs-WIP, 145-150. http://ceur-ws.org/Vol2356/experience_short11.pdf

King, M., Pegrum, M., \& Forsey, M. (2018). MOOCs and OER in the global south: Problems and potential. The International Review of Research in Open and Distributed Learning, 19(5). 
https://doi.org/10.19173/irrodl.v19i5.3742

Kizilcec, R. F., Piech, C., \& Schneider, E. (2013). Deconstructing disengagement: Analyzing learner subpopulations in massive open online courses. Proceedings of the Third International Conference on Learning Analytics and Knowledge, 170-179. https://doi.org/10.1145/2460296.2460330

Kizilcec, R. F., Reich, J., Yeomans, M., Dann, C., Brunskill, E., Lopez, .. . Tingley, D. (2020). Scaling up behavioral science interventions in online education. Proceedings of the National Academy of Sciences, 1-6. https://doi.org/10.1073/pnas.1921417117

Kop, R. (2011). The challenges to connectivist learning on open online networks: Learning experiences during a massive open online course. The International Review of Research in Open and Distributed Learning, 12(3), 19-38. https://doi.org/10.19173/irrodl.v12i3.882

Kop, R., Fournier, H., \& Mak, J. S. F. (2011). A pedagogy of abundance or a pedagogy to support human beings? Participant support on massive open online courses. The International Review of Research in Open and Distributed Learning, 12(7), 74-93. https://doi.org/10.19173/irrodl.v12i7.1041

Lambert, S. (2020). Do MOOCs contribute to student equity and social inclusion? A systematic review 2014-18. Computers \& Education, 145, 103693. https://doi.org/10.1016/j.compedu.2019.103693

Lee, J., Hong, A., \& Hwang, J. (2018). A review of massive open online courses: MOOC's approach to bridge the digital divide. The 22nd Biennial Conference of the International Telecommunications Society. Seoul, South Korea: International Telecommunications Society. Retrieved from https://www.econstor.eu/bitstream/10419/190394/1/E3 3 Lee-et-al.pdf

Li, Y. (2017). Massive open online courses (MOOCs) in the United States, China and India. 2017 2nd International Conference on Modern Management, Education Technology, and Social Science (MMETSS 2017), 130-137. https://doi.org/10.2991/mmetss-17.2017.27

Liyanagunawardena, T., Adams, A., \& Williams, S. (2013). MOOCs: A systematic study of the published literature 2008-2012. The International Review of Research in Open and Distributed Learning, 14(3), 202-227. https://doi.org/10.1037/ho037492

Ma, L., \& Lee, C. S. (2019). Understanding the barriers to the use of MOOCs in a developing country: An innovation resistance perspective. Journal of Educational Computing Research, 57(3), 571-590. https://doi.org/10.1177/0735633118757732

Margaryan, A., Bianco, M., \& Littlejohn, A. (2015). Instructional quality of massive open online courses (MOOCs). Computers \& Education, 80, 77-83. https://doi.org/10.1016/j.compedu.2014.08.005

Martin, F. G. (2012). Will massive open online courses change how we teach?. Communications of the $A C M$, 55(8), 26-28. https://doi.org/10.1145/2240236.2240246 
Martí-Parreño, J., Méndez-Ibáñez, E., \& Alonso-Arroyo, A. (2016). The use of gamification in education: A bibliometric and text mining analysis. Journal of Computer Assisted Learning, 32(6), 663-676. https://doi.org/10.1111/jcal.12161

Nordin, N., \& Norman, H. (2018). Cross-culture learning via massive open online courses for higher education. Jurnal Pendidikan Malaysia [Malaysian Journal of Education], 43(1), 35-39. https://doi.org/10.17576/jpen-2018-43.01-05

Pan, R., Kaski, K. \& Fortunato, S. (2012). World citation and collaboration networks: Uncovering the role of geography in science. Scientific Reports, 2, 902. https://doi.org/10.1038/srepoogo2

Radford, A., Robles, J., Cataylo, S., Horn, L., Thornton, J., \& Whitfield, K. (2014). The employer potential of MOOCs: A mixed-methods study of human resource professionals' thinking on MOOCs. International Review of Research in Open and Distributed Learning, 15(5), 1-25. https://doi.org/10.19173/irrodl.v15i5.1842

Reich, J. (2015). Rebooting MOOC research. Science, 347(6217), 34-35. https://doi.org/10.1126/science.1261627

Rogers, R. A. (2007). The Shanghai Cooperation Organization, China and the new great game in Central Asia. Journal of International Studies, 3, 92-105. http://jis.uum.edu.my/images/pdf/3jis/6theshanghaii.pdf

Rohs, M., \& Ganz, M. (2015). MOOCs and the claim of education for all: A disillusion by empirical data. International Review of Research in Open and Distributed Learning, 16(6), 1-19. https://doi.org/10.19173/irrodl.v16i6.2033

Sweileh, W. M., Al-Jabi, S. W., AbuTaha, A. S., Sa'ed, H. Z., Anayah, F. M., \& Sawalha, A. F. (2017). Bibliometric analysis of worldwide scientific literature in mobile-health: 2006-2016. BMC Medical Informatics and Decision Making, 17(1), 72. https://doi.org/10.1186/s12911-017$\underline{0476-7}$

United Nations General Assembly. (2015) Transforming our world: The 2030 Agenda for sustainable development. United Nations. Retrieved from https://sustainabledevelopment.un.org/content/documents/21252030\%20Agenda\%20for\%2 oSustainable\%20Development\%20web.pdf

Veletsianos, G., \& Shepherdson, P. (2015). Who studies MOOCs? Interdisciplinarity in MOOC research. The International Review of Research in Open and Distributed Learning, 16(3), 117. https://doi.org/10.19173/irrodl.v16i3.2202

Veletsianos, G., \& Shepherdson, P. (2016). A systematic analysis and synthesis of the empirical MOOC literature published in 2013-2015. International Review of Research in Open and Distributed Learning, 17(2), 1-16. https://doi.org/10.19173/irrodl.v17i2.2448

van Eck, N. J., \& Waltman, L. (2014). Visualizing bibliometric networks. In Y. Ding, R. Rousseau, \& D. Wolfram (Eds.), Measuring scholarly impact (pp. 285-320). Cham, Switzerland: Springer. https://doi.org/10.1007/978-3-319-10377-8 13 
Verk, N., Golob, U., \& Podnar, K. (2019). A dynamic review of the emergence of corporate social responsibility communication. Journal of Business Ethics, 1-25.

https://doi.org/10.1007/s10551-019-04232-6

Yousef, A. M. F., Chatti, M. A., Schroeder, U., Wosnitza, M., \& Jakobs, H. (2014). MOOCs: A review of the state-of-the-art. CSEDU 2014: Proceedings of the 6th International Conference on Computer Supported Education, 3, 9-20. https://doi.org/10.5220/0004791400090020

Zancanaro, A., \& Domingues, M. J. (2017). Analysis of the scientific literature on massive open online courses (MOOCs). Ried-Revista Iberoamericana De Educacion a Distancia [Ibero-American Distance Education Magazine], 20(1), 59-80. https://doi.org/10.5944/ried.20.1.15910

Zancanaro, A., \& Domingues, M. J. (2018). Massive open online courses (MOOC) for teaching Portuguese for foreigners: A case study. Turkish Online Journal of Distance Education, 19(2), 4-20. https://doi.org/10.17718/tojde.415602

Zancanaro, A., Todesco, J. L., \& Ramos, F. (2015). A bibliometric mapping of open educational resources. International Review of Research in Open and Distributed Learning, 16(1). https://doi.org/10.19173/irrodl.v16i1.1960

Zheng, S., Rosson, M. B., Shih, P. C., \& Carroll, J. M. (2015). Understanding student motivation, behaviors and perceptions in MOOCs. Proceedings of the 18th ACM Conference on Computer Supported Cooperative Work \& Social Computing, 1882-1895. https://doi.org/10.1145/2675133.2675217

Zhu, M., Sari, A., \& Bonk, C. J. (2018a). A systematic review of MOOC research methods and topics: Comparing 2014-2016 and 2016-2017. EdMedia + Innovate Learning (pp. 1673-1682). Amsterdam, Netherlands: Association for the Advancement of Computing in Education. Retrieved from http://www.trainingshare.com/pdfs/june-27/Ed MediaProceedings 2018 MOOC research review Zhu Sari Bonk Amsterdam.pdf

Zhu, M., Sari, A., \& Lee, M. M. (2018b). A systematic review of research methods and topics of the empirical MOOC literature (2014-2016). Internet and Higher Education, 37, 31-39. https://doi.org/10.1016/j.iheduc.2018.01.002

\section{Athabasca University}

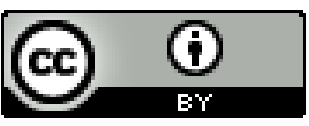

